\title{
Study on the status quo of the lack of peasant workers' ideological quality education and the construction of harmonious environment
}

\author{
Li Jie \\ Xijing university, Xi'an, 710123, China
}

Keywords: peasant workers' education, the ideological and political, harmonious environment

\begin{abstract}
The peasant workers became the main force in the construction of modernization and at the same time, there are a series of problems, which seriously affected the stability and harmony of the social. In this paper, we did further explore on the ideological and political education of peasant workers based on the status quo of peasant workers' ideological and political education, and put forward some countermeasures to solve the problem. The ideological and political education of peasant workers is a long-term and complex project. It needs the cooperation of the country, the relevant government departments, the enterprises and peasant workers to ensure the project taken smoothly and achieve remarkable results.
\end{abstract}

\section{Introduction}

The peasant worker is the inevitable product in the transformation from traditional agricultural society to modern industrial society since Chinese reform and opening up and also is new thing in China implement the strategy of industrialization and urbanization with distinctive Chinese features and characteristics. Peasant workers participate in the construction of city, make great contributions to the development of city, they are China's important economic and social development relying strength.

Peasant workers ideological and political education refers that the society aims at the factors which is not appropriate to the various and modern development such as old ideology, the low quality, by the modern ideas, scientific world outlook, outlook on life, values and methodology give some planned and organized effect to peasant workers. Liberate their ideological, to update the concept, thus to improve the work skills and overall quality. At the same time, try to improve their ability of self-development, eventually make peasant workers become full, free and harmonious development modern people.

\section{Analysis on the lack of ideological and political education present situation of Chinese peasant workers}

\section{Education environment is bad}

Because peasant workers work outside for a long time, considering the economic factors, they rarely return to census register seat to enjoy the corresponding political rights and interests, and in the city, enterprises and units they work, they have no right to participate in political activities, and as a Chinese citizen virtually lost the most basic right to vote and be elected and the rights of the most general to participate in the enterprise management. Again, due to the special status of peasant workers, they do the dirty tired physical labor mostly which urban citizens are not willing to do, this leading citizens have serious discrimination and prejudice to peasant workers. It is difficult for peasant workers to go into the city resident's life, they can not enjoy urban civilization and advanced life, culture and entertainment facilities, and they are lack of the harmonious humanities environment for ideological and political education.

\section{Ideological and political education lags behind the skills training}

Our education to peasant workers tend to just pay attention to the training of peasant workers' skills and professional quality, rarely from the perspective of ideological and political education to understand their words and deeds and thought. When the fair wages and social security are met, they also have other higher level of demand, they also hope to improve culture of ourselves and 
future generations, change the living conditions marginalized by urban citizens. They hope to share the results brought by the construction of socialist modernization together with urban residents, hope to improve the ability of own foothold in the city, strive to become a new resident in city, change the fate discriminated by people. So, in the practice of ideological and political education, in the training of peasant workers, we can't just stay on the skills training, but must also carry on the patriotism, collectivism and socialism education, help them to set up the correct outlook on life, world outlook and values, make their professional ethics, social ethics and family virtues improve together with their labor skills.

\section{Education goal is not clear}

The fundamental goal of Chinese ideological and political education is to improve the ideological and moral qualities of people, promote the overall development of people, motivate people struggle for the construction of socialism with Chinese characteristics and finally realize the communism. What we pay attention to in their education and training is often "can obtain employment", in the process of employment achieve the "no accident" goal .This kind of low-level ideological and political education goal directly led to that the educators have narrow choice in the education content.

\section{Pertinence is not strong}

Peasant workers work into the city, their work presents the diverse and uncertain but educators often ignore their individual differences and individual in the process of ideological and political education. At the same time, educators do not take the different methods and content according to the different jobs in the ideological and political education. Not for peasant workers' differences in ideology and culture quality, the different situation of individual, exert purposeful, planned and organized ideological and political education. Educators do not exert purposeful, planned and organized ideological and political education to different people aiming at differences in ideology and culture quality of peasant workers. The different conditions of individual, type of work and region, the life original, the education and so on determine that the individual's world outlook, the outlook on life, the values of peasant workers are different, thus determines the differences of survival way and the principle and also the concept and time blending in the city life.

\section{Harmonious environment construction countermeasures in ideological and political education work of peasant workers}

Current China is in the socialist transformation period, status of peasant workers is inevitably put in a embarrassing situation. Combined with that the ideological and political education for peasant workers work does not reach the designated position, a series of questions about peasant workers are caused. Peasant workers are the mainstay of modernization construction, they are related to Chinese future economic development and modernization progress. Therefore it is imperative to strengthen the ideological and political education of peasant workers, make the ideas of the group to achieve the modernization of human modernization standard.

To strengthen the ideological and political education of peasant workers has the vital significance

Economic base determines the superstructure, this Marx's famous claim explains that the "ideological and political work is the lifeline of economic work and all other work". To strengthen the ideological and political education work of peasant workers, improve the group's overall quality and thinking consciousness has great significance for China's socialist modernization.

1)Promote sustainable economic development and maintain social stability.

Peasant workers is an important link between China's urban and rural areas, a large number of farmers influx into cities, brought plenty of cheap labor for urban society and modernization, and also led to the rural economic development in less developed areas. China is still in the primary stage of socialism, most of the industry is labor-intensive enterprises. The low wages of peasant workers greatly reduces the production cost of industrial sector, this makes a lot of small businesses sprung up flourished. To strengthen the ideological and political education of peasant workers, to maintain social stability and the city's security has great significance. 
2)Raise the level of own cultural quality and moral of peasant workers.

Due to restricted by economic condition, peasant workers generally do not have a high level of education. The lack of knowledge, the thought idea, behavior of backward make the whole quality of this group be in a relatively low level. Since the founding of the country, although countries intensify the tilt on the cause of education, but due to reasons such as history and geography, rural education level still has no fundamental improvement. The peasant workers is the main force of China's modernization, and their cultural quality have direct relationship with the development of China. Fully arouse their working enthusiasm, initiative and creativity, improve the peasant workers group spirit, provided a basis for modernization of human modernization, do sufficient preparation.

3)To accelerate the process of the integration of urban and rural areas.

Industrialization and modernization is the inevitable developing law of China's economy, the followed urban and rural integration also received great importance of the party and the government. Peasant workers is an irreplaceable force in the construction of socialist modernization, they play an important role in the process of urban-rural integration. Peasant workers is also a process from the peasants to urban residents. To strengthen the ideological and political education of peasant workers, make them faster integrate into city life, shorten the gap between urban and rural areas, is advantageous to the exchanges and communication between urban and rural areas. The work to strengthen the ideological and political education of peasant workers, is not only targeted at rural peasant workers in terms of personal development, but also prepared to build a harmonious society and urban and rural integration.

\section{Optimization of the macro environment of peasant workers' ideological and political education}

Conceptually, ideological and political education environment refers to the sum of all the external factors of the ideological and political education activity and object of ideological and political education of ideology and moral character influence to the formation and development, including the macro conditions of the ideological and t the object in the microscopic environment. In the process of ideological and political education of peasant workers, we should pay attention to the optimization of ideological and political education environment, reasonably using the positive factors in the environment, fully play its role to promote the development of people, to achieve the desired effect of the ideological and political education. Peasant workers is the special group of Chinese urban society, and basically in a discriminatory and unfair social environment, the environment of ideological and political education of peasant workers has many adverse impact. To improve the effect of the ideological and political education work of peasant workers, must try to build a relatively loose and harmonious social environment.

\section{Optimize the micro environment of ideological and political education of peasant workers}

As the object of the education of ideological and political education, peasant workers have certain scope of life practice, this group in the different scope of life is affected by the different education environment. We can call the specific scope of life practice the microcosmic environment of ideological and political education of peasant workers, it includes the community environment, business environment and family environment, micro environment on the formation of people's ideology and moral character also plays an important influence and restriction role.

\section{Optimize the environment of the community}

To optimize the ideological and political education of the community culture of $r$ peasant workers mainly refers to that through community life order, community culture, community culture, interpersonal and ethics to form a positive impact to development and political quality of peasant workers. Government should invest to build a number of peasant workers gathered center with residential, education training, management services and cultural entertainment in the integration, low-rent lease to those peasant workers in the form of low-priced. Provide convenient service life and psychological aid to peasant workers, rich their amateur life, make them to blend in the local culture of living environment using the shortest time, let the peasant workers blend in urban social life more easily. 


\section{Optimize the environment of the enterprise}

To optimize the environment of enterprises is to optimize the work environment of rural peasant workers. Work environment is the life data of a person to obtain the survival and development, is an important place to show their talent, realize their life values. The construction of a harmonious enterprise environment is an important aspect of ideological and political education environment optimization. To profit is the main purpose of the enterprise, and the employee's hard work is the most important guarantee of corporate profits. As the enterprise's employees if peasant workers are in the work environment of a lack of fairness and justice, it will breeds discontent, restrain their work enthusiasm, initiative and creativity, such not only hindered the development of enterprises, but also against the development of rural peasant workers themselves, so the enterprises to build a good environment. In addition, still should strengthen the on-the-job training of peasant workers, through professional skill training, constantly to improve the quality of peasant workers to get development and progress common with enterprise.

\section{Optimize the environment of family}

Family is the basic social organization form, is a cell of the society. For most peasant workers, home is their heart truly belongs to. Family thoughts often makes peasant workers can't set his mind at the work in the city, lacking of sense of belonging. Therefore, to improve the ideological and political education of peasant workers must optimize the environment of the home environment, help peasant workers to establish a positive attitude, strengthen their ability to control themselves and moral constraints.

\section{Conclusion}

In recent years, problems of the peasant workers emerge in endlessly, peasant workers has been widespread attention in real life. The peasant workers is the main force of China's modernization, their quality is closely related to our harmonious society construction. Many ideological problems existing in their development process, are not only unfavorable to the development of their own, but also has brought a lot of hidden dangers to social harmony and stability. So to strengthen the ideological and political education of peasant workers, peasant workers ideological and political education system, is not only beneficial to the improvement of quality of peasant workers, enhance their consciousness of maintaining their rights, but also to compensate for the loss of peasant workers in thinking, cultivate their dedication, service to the modernization construction better.

\section{References}

[1] Liu Huailian. The problem of Chinese farmers. Beijing: people's publishing house, 2005.26.

[2] Wu Baoshan. The psychological characteristics of peasant workers and the ideological and political education [J]. Journal of economic and social development, 2006.11.

[3] Chen Wanbai ,Zhang Yaocan. Principle of ideological and political education. Beijing: higher education press, 2007.94.

[4] Li Yamin. The question of ideological and political education in the new period analysis.anhui agricultural science, 2008.15.

[5] Shen Guoquan. Ideological and political education environmental.Shanghai: fudan university press, 2002.56.

[6] Abraham maslow. Human incentive theory. Popular science press, 1943.73.

[7] Chen Weidong, Wu Zelin. Peasant workers ideological and political education present situation and countermeasure research. hunan BBS, 2011.56.

[8] Lu Xueyi. The contemporary Chinese social mobility [M]. Beijing: social sciences academic press, 2004.24. 